\title{
木造軸組構造の実用的な静的弾塑性解析手法 \\ PRACTICAL PROCEDURES FOR STATIC ELASTO-PLASTIC ANALYSIS \\ OF TIMBER STRUCTURE
}

\author{
渡辺智子*, 東樋口 護**, 立石 一***, 徐 廷 禹* \\ Tomoko WATANABE, Mamoru TOUHIGUCHI, Hajime TATEISHI \\ and Jung-Woo SUH
}

\begin{abstract}
This paper presents numerical analysis procedures to evaluate static elasto-plastic behavior of wooden timber structures under horizontal loadings by using a ready-made structural analysis program. To evaluate the special property of structures, following models are used;

1) virtual floors without in-plane rigidity to evaluate stiffness and strength of hanging and spandrel walls,

2) wall stiffness reduction factors to evaluate the semi-rigidity at end connections of the columns and girders in the axial direction. Numerical values needed for each models are obtained from loading tests. The validity of profosed models are confirmed by the results of loading tests.
\end{abstract}

keywords : timber structure, numerical analysis, hanging wall, spandrel wall, semi-rigid connection, space frame 木構造、数值解析、垂壁、腰壁、半剛接、立体解析

1.はじめに

木質構造建築物の構造設計法に関して、多くの実験研究が行われ ている。その成果をもとに、宮澤の壁要素のブレース置換に関する 研究1)やまた立体弾塑性解析に関する研究 ${ }^{23)}$ 面材や剛接合の弾塑性 解析に関する研究) そして在来軸組工法の構造設計手法に関する稲 山村上らの一連の研究 ${ }^{(5) 6)}$ な゙示唆に富む多くの提案が示されている。 しかし、木質構造建築物の大半を占める住宅の構造計算の主流は、 「壁量計算」を基にしたものと思われる。この計算法は簡便である が、木構造の力学的諸性能を包括的に評価できない場合がある。壁 量計算の手法は以下の特徵を有する。

(1) 柱・梁が小径材であれば、妥当と考えられるケースも多いが、 大黒柱等の大きな部材断面は評価の対象外となる。

(2) 垂壁・腰壁および幅の狭い壁は剛性や耐力にカウントされない。

(3) 床構面は、剛床仮定を前提としたものである。

実際に建築される住宅では、計画的な要請で上下階で耐力壁の位 置がずれたり、極端に壁を嫌う部分があり、壁量計算による設計で は建築の計画的な要求を充足し難い場合がある。これらの要求を充 たしながら解析精度が高くかつ簡便で実用的な設計手法と解析手法 が望まれる。

本稿は、木造軸組構造の設計で現在直面する困難の一部を解決す
る方法の提案である。また、本論で提案する構造計算方法は、建物 の構造的性能を定量的にとらえることを主な目的とし、また、対象 木造建築物の適用範囲を拡げ、多様な構造形式に対応できることを 目標にしている。その計算方法は以下の特徴をもつ。

(1) 既存の構造設計ブログラム（一貫計算プログラム）を利用して 解析する。

(2) 木構造を耐力壁併用ラーメン架構にモデル化して解析を行う。

(3) 非剛床解析を行うため、剛床仮定の制約から解放されて床の変 形および床版各部の応力を解析できる。また、耐力壁が上下階 でずれたり床開口があっても各部の挙動を解析的に追跡できる。

(4) 垂壁, 腰壁, 幅の狭い壁を耐力要素に組み込み、正当に評価す る解析が可能である。

(5) 大黒柱等の大きな断面部材も、正当に評価できる。

(6) 耐震性能は弾性域のみならず、弾塑性域にわたり追跡する。 解析には建築物の構造設計支援ツールとして一般的に広く使われ ている一貫計算ブログラムを使用する。このプログラムは RC造、 S造、SRC造建築の構造設計システムであるが、材料特性に木造の值 を入力することにより、木構造の解析を行うことができる。

注）使用プログラム：BUILD-1（踌)NTT データ DEMOS）
**(株)立石構造設計

**鳥取環境大学環境デザイン学科 教授・エ博

*** 株立石構造設計代表取締役 工修
Tateishi Kozo-Sekkei Inc.

Prof., Dept. of Environmental Design, Tottori Univ. of Environmental Studies, Dr. Eng.

Director, Tateishi Kozo-Sekkei Inc., M. Eng. 


\section{2. 解析モデル}

\section{1 基本方針}

垂壁や腰壁を解析モテルに組み込むため、垂壁下端と腰壁上端レ ベルに仮想の層を設けた解析モテルを採用する。このモデルを高い 精度で解析するためには、水平構面が存在する層のみに水平剛性を 考慮する非剛床解析が必要条件となる。使用ブログラムは、弾性解 析においては立体モデルによる非剛床解析が可能であり、水平構面 各部の変形・応力状態が把握できる。ただし、プログラムの制約と して、静的弾塑性解析においては剛床を前提とした擬似立体モテル で解析を行い、仮想の層は全ての節点において剛床の解除を行う。 プログラムにおいて、剛床仮定を解除する節点は、各部材の荷重一 変位方程式でその節点の水平変位を独立にとり、骨組み全体の荷重 一変位方程式において独立の未知数として扱われる。

空台・まぐさを含む柱・梁等の軸組材は、軸・曲げ・せん断剛性 を考慮し、弾性の線材に置換する。耐力壁は弾塑性ブレースに置換 する。床版は、面内剛性を考慮し、面外に関しては剛体として扱う。

\section{2 接合部のモデル化と壁剛性低減率}

木構造に特有の力学的特性として、接合部の半固定接合を適切に 取り入れた解析が要求される。接合部の軸方向に関する固定条件は、 引張側は引抜き抵抗が弱いため軸変形が大きく、圧縮側は木材同士 の支圧により抵抗が大きいため軸変形が小さい。したがって、軸方 向に関する固定条件は引張側と圧縮側とでバネ定数を変える必要が ある。しかし、一般的な平面・立体解析プログラムでは、図1のよ うに節点に柱・梁・ブレース等の部材が接合する形式であり、軸方 向バネを入力しても、ブレースに置換した耐力壁による引き抜き力 が直接節点に入ってしまい、モテル化として不完全なものとなる。

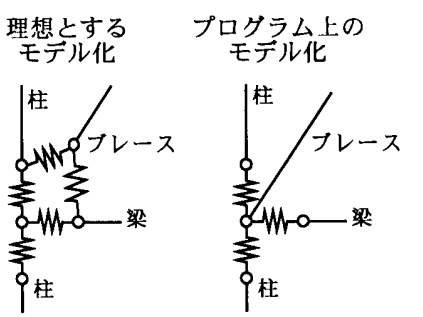

図1 柱とブレースの接合部

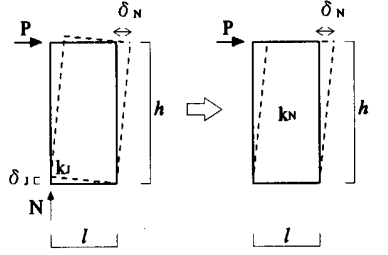

図2 浮き上がりを壁剛性に置換
接合部の中でも、柱脚は浮き上がり変位が特に大きく無視できな い。このため、図2のように浮き上がりによる水平変位を耐力壁の せん断変形とみなし、耐力壁の剛性を低減させることにより柱脚金 物の軸剛性を評価することとする。柱脚の軸方向半固定を考慮して 耐力壁の剛性を本来のせん断剛性から低減させる割合を「壁剛性低 減率」と呼ぶこととする。その他の接合部のモデル化を表1に示す。

表1 接合部のモデル化

\begin{tabular}{|c|c|c|c|c|c|}
\hline & & & 材軸方向 & 材軸直交方向 & 回転方向 \\
\hline \multicolumn{3}{|c|}{ 梁接合部 } & 風 & 剛 & 自由～半剛 \\
\hline \multirow{3}{*}{ 柱接合部 } & \multicolumn{2}{|c|}{ 柱頭 } & 㴊 & 㴊 & 自由 \\
\hline & \multirow{2}{*}{ 柱脚 } & 圧縮側 & 剛 & \multirow{2}{*}{ 剛 } & \multirow{2}{*}{ 自由 } \\
\hline & & 引張側 & 半剛 $\rightarrow$ 㴊 & & \\
\hline
\end{tabular}

注）回転剛性は、特殊な金物により接合した場合は半剛接合とするが、 般的な在来軸組工法の仕口はピンとしてモデル化する。
図2より、柱脚の浮き上がりによる壁剛性 $k_{\mathrm{N}}$ は、軸バネ $k_{\mathrm{J}}$ を用 いて式(1) により表すことができる。

$$
k_{N}=k_{J} \frac{l^{2}}{h^{2}}
$$

垂壁・腰壁の付いていない耐力壁の場合において、浮き上がりを 考慮した耐力壁の剛性は、本来の壁剛性 $k \mathrm{~g}$ と浮き上がりによる剛 性 $k$ Nを合成して式(2)で表される。

$$
\frac{1}{k_{Q}}=\frac{1}{k_{g}}+\frac{1}{k_{N}}
$$

垂壁や腰壁の付いた耐力壁の場合は、柱脚浮き上がりの影響を受 ける部分を図 3 範囲とする。浮き上がりによる剛性 $k_{N}$ は、引張側 柱脚の支点に軸バネ $k$, を設定して弾性解析を行い、水平力 $P$ と浮 き上がり量 $\delta$,を求めて壁要素毎に式 (3)により算定できる。

$$
k_{N}=\frac{P}{\delta_{N}}=\frac{P \cdot l}{\delta_{J} \cdot h}
$$

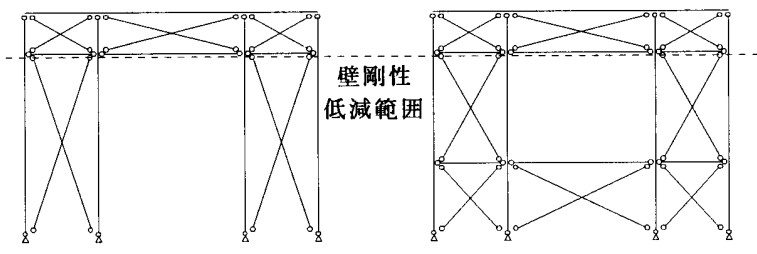

図3 壁剛性低減範囲

壁剛性低減率は、浮き上がりを考慮した耐力壁の剛性 $k$ Q と耐力 壁本来の剛性 $k_{\mathrm{g}}$ の比として式 (4)の通りとなる。

$$
\alpha=\frac{k_{Q}}{k_{g}}
$$

柱脚の浮き上がりに影響を与える要素は、垂壁・腰壁の有無と開 口位置での壁長であると考えられる。そこで害用式として耐力壁の タイプ毎に壁剛性低減率を設定し、建物全体の解析を行うこととす る。

解析モデルの検証を行うために、垂壁の付いた合板釘打ち耐力壁 について実大実験を行った。引張側柱脚の支点を軸方向バネとした 「バネモテル」と、柱脚の浮き上がりを考慮して壁剛性を低減させ た「ピンモデル」の 2 つのモテルについて実験結果と解析結果の比 較検討を行う。
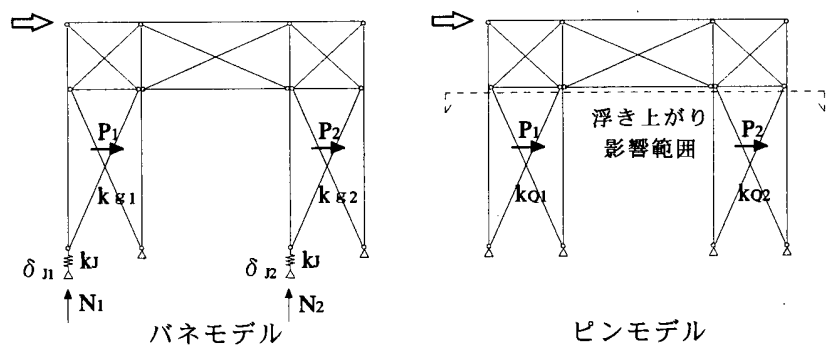

図4垂壁付き耐力壁の解析モデル 


\section{3. 合板釘打ち耐力壁実倹}

\section{1 実倹供䳝体}

供試体 No. I 〜 I の4種類16体の供試体について実験を行った。 供試体の形状を図9に示す。供試体は、構造用集成材の軸組材（樹 種 : 欧州アカマツ) に構造用合板（2 級）を四周 CN50@100 で両 面釘打ちしたものである。垂壁受材に柱と同様の集成材（105×10 5）を用い、柱との接合部はクレテック金物、新たに考案された三 角金物（No. N のみ、図7）を使用した。No. INの柱脚は実験用に考 案された沓金物（図8）を使用し、ピン接合とした。

\section{2 加力と計測}

図6の装置により、無載荷式で西側柱頭 (C1) に水平荷重を加えた。 試験体4体のうち3体は図5のように正負繰り返し加力実験を、1体は 単調加力実験を実施した。各加力ステップにおいて3回ずつ繰り返 し載荷し、層間変形角 $1 / 1000 \mathrm{rad}$ 以内の刻み幅で各計測デー夕を モニタリングした。最終的には、荷重が $0.8 \mathrm{P}_{\max }$ に降下するまで東方 向（押し方向）に斬増載荷した。 各供試体ごとに、東側柱 (C4)の 水平変位を巻き込み型変位計で、柱梁接合部をパイ型変位計で測定 した。また柱と金物（ホールダウン金物、三角金物、沓金物）のひ ずみを静ひずみ計で、土台の浮き上がりを高感度変位計で測定した。

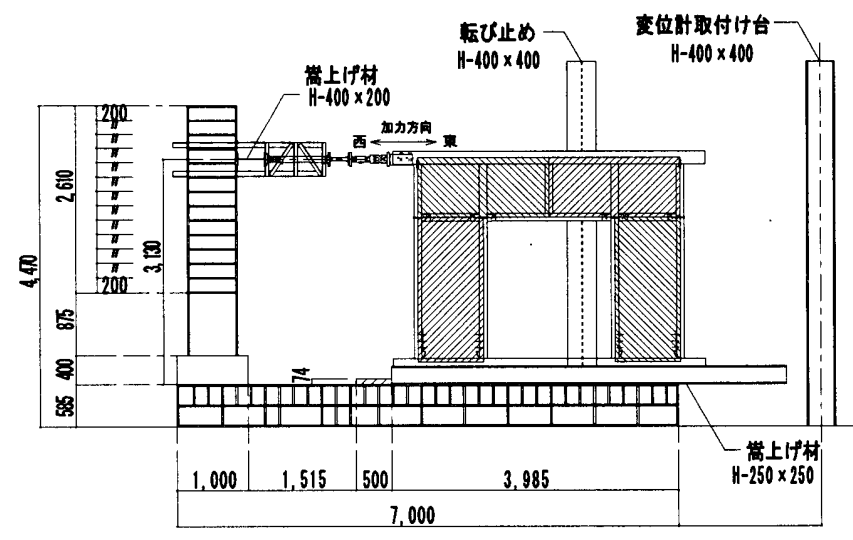

図6 セットアップ図

\section{3 各部の特性}

3. 3.1 柱 $\cdot$ 梁部材

材料試験の結果を表2に示す。柱・梁部材のヤング係数と圧縮強 度・曲げ強度は、圧縮試験と曲げ試験 3体の平均值とする。せん断 弾性係数は曲げヤング係数の $1 / 15$ 、他の強度はJAS規格値として解 析を行う。

表2 柱・梁部材と材料試験結果

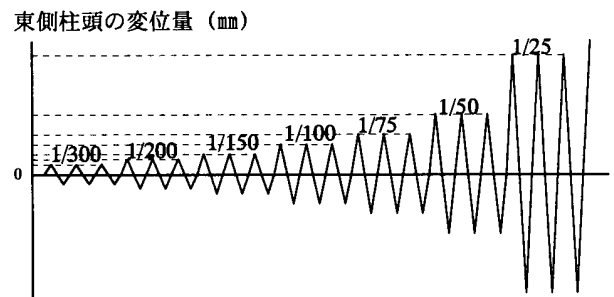

図5 加カステップ

\begin{tabular}{|c|c|c|c|c|c|}
\hline \multirow{2}{*}{ 断面寸法 } & \multirow{2}{*}{ 強度等級 } & \multicolumn{4}{|c|}{ 材料試験結果（3 体平均） $\mathrm{N} / \mathrm{mm}^{2}$} \\
\hline & & 圧縮 E & 曲げ E & 圧䑿強度 & 曲け強度 \\
\hline $105 \times 105$ & E85-F300 & $8.07 \times 10^{3}$ & $11.28 \times 10^{3}$ & 40.59 & 44.84 \\
\hline $\begin{array}{c}105 \times 240 \\
(105 \times 180)\end{array}$ & E120-F330 & $10.56 \times 10^{3}$ & $11.37 \times 10^{3}$ & 41.42 & 42.03 \\
\hline
\end{tabular}

注）曲げ試験はJAS規格 構造用集成材 曲げA試験による。
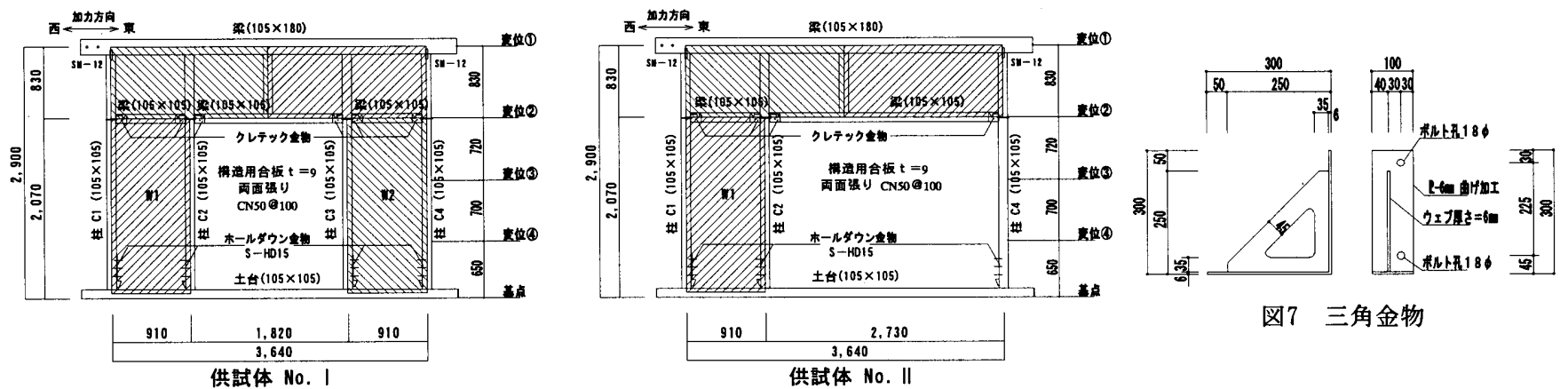

図7 三角金物
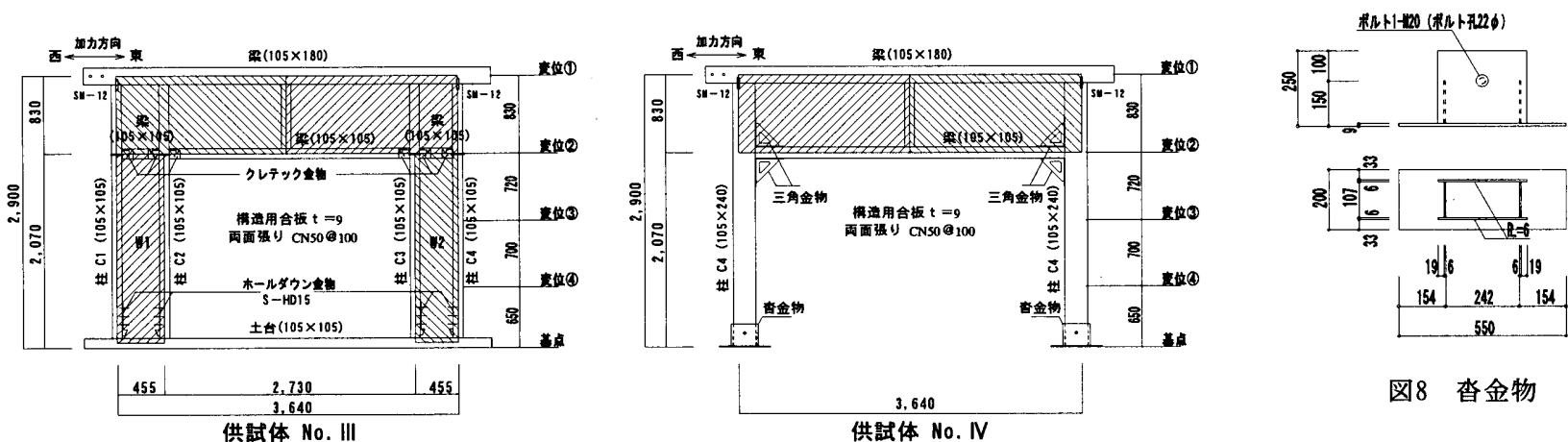

図8 沓金物

実験供試体 


\section{3.2 接合部}

柱脚金物の軸特性を図10に示す。S-HD15 の引張剛性と最大変位 は、文献8）「S-HD使用の実験結果」 20 体の平均值とする。引張耐力 は、柱の圧縮試検結果を用いてボル卜接合部のせん断耐力式により 算定する。

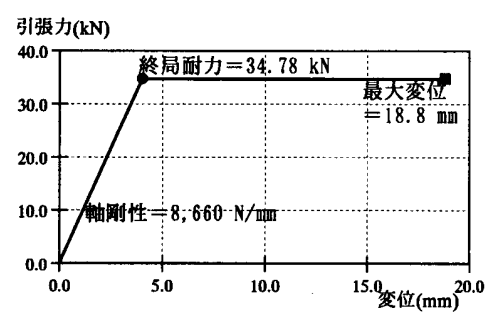

図10 柱脚金物の軸特性（引張）

三角金物を使用した接合部の回転剛性は、図11の接合部実験より $5.0 \mathrm{kNm} / \mathrm{rad}$ とする。接合部の耐力は、接合部実験が軸材の曲げ破 壊で終了したため軸材の曲け耐力とする。

沓金物は回転方向・軸方向共にピン接合とする。耐力は柱の圧維 試験結果から、ボルト接合部のせん断耐力式により算出する。
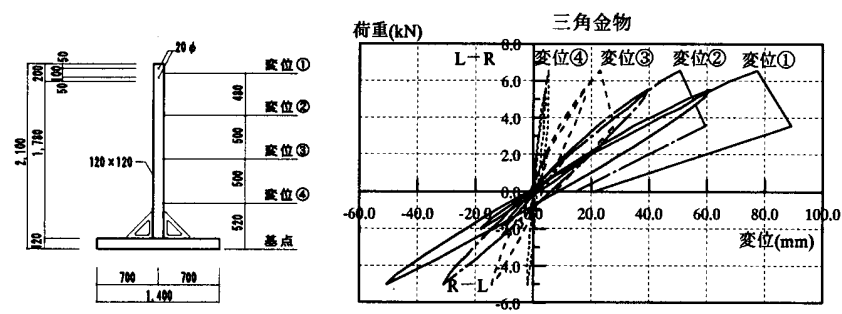

図11 三角金物接合部実験

\subsection{3 合板釘打ち耐力壁}

合板釘打ち耐力壁は、文献7）の式(5)、（6）に基づいて剛性と耐力 を算定する。釘の一面せん断降伏耐力は文献7)の値とするが、釘の すべり剛性の值は文献9)の実験値「合板 $9.5 \mathrm{~mm}, \mathrm{CN} 50$, 綝り返し加力 の平均値」を用いる。文献 10$)$ より釘の最大すべりを $25 \mathrm{~mm}$ とし、限 界層間変位を $50 \mathrm{~mm}$ とする。耐力壁の特性を図 12 に示す。

合板釷打ち耐力壁の剛性 $k \mathrm{~g}$, 降伏耐力 $Q_{y}$, 終局耐力 $Q_{u}$

$$
\begin{aligned}
& \frac{1}{k_{g}}=\frac{2 h}{k_{n}}\left[\frac{1}{h \cdot(m-1)}+\frac{h}{l_{0}{ }^{2} \cdot(n-1)}\right]+\frac{h}{G l_{0} t} \\
& Q y=q \cdot s \cdot \frac{h}{l_{0}}, \quad Q_{u}=1.5 \cdot Q_{y}
\end{aligned}
$$

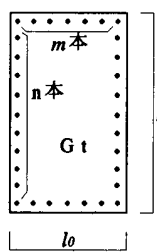

$$
\text { すべり剛性 }: k_{n}=1,250 \mathrm{~N} / \mathrm{mm}
$$

一面せん断降伏耐力： $q=590 \mathrm{~N}$

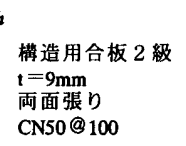

釘本数による係数: $s=\min \left[\begin{array}{l}m-1 \\ (n-1) \frac{l_{0}}{h}\end{array}\right.$ CN50@100

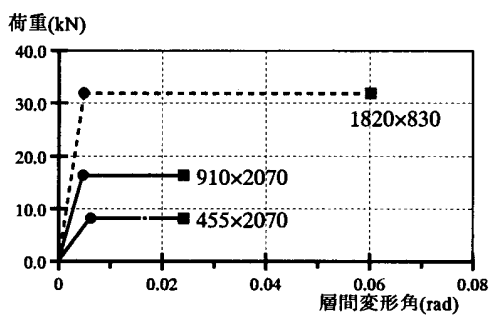

図12 耐力壁の特性

\section{3.4 壁剛性低減率}

供試体No. I 〜IIIおけるピンモデルの壁剛性 $k$ Qは、式(3)に基 づいて算定し表 $3 の$ 值とする。式(5)により算定した本来の壁剛性 $k_{\mathrm{g}}$ に対する低減率は $0.54 \sim 0.66$ である。また、柱脚の浮き上が りを考慮すると、耐力壁W1, W2 となる。

\begin{tabular}{|c|c|c|c|c|c|c|c|}
\hline & $P$ & $\delta$ & $\begin{array}{c}k \mathrm{~N} \\
\text { 浮上り }\end{array}$ & $\begin{array}{c}k \mathrm{~g} \\
\text { 釘·合板 }\end{array}$ & $k e$ & $\begin{array}{c}\text { 壁剛性低減率 } \\
k \mathrm{a} / k \mathrm{~g}\end{array}$ \\
\hline \multirow{2}{*}{ No. I } & $\mathbb{1} 1$ & 7547 & 1.757 & 1888.3 & 1686.2 & 890.8 & 0.54 \\
\hline & W2 & 9341 & 1.232 & 3333.1 & 1686.2 & 1119.7 & 0.66 \\
\hline No. II & W1 & 9087 & 1.988 & 2009.5 & 1686.2 & 916.9 & 0.55 \\
\hline \multirow{2}{*}{ No. III } & W1 & 2876 & 0.872 & 725.4 & 623.1 & 335.2 & 0.54 \\
\hline & 12 & 3311 & 0.691 & 1053.5 & 623.1 & 391.5 & 0.62 \\
\hline
\end{tabular}

表3＼cjkstart浮上り考慮の壁剛性と壁剛性低減率

$(\mathrm{N}, \mathrm{mm})$

\section{4 解析結果}

各供試体について、変位計(1)の変位を 1.0 とした場合のC4の変形 状態を図13に示す。No. I は実験值と解析結果がほとんど一致して いる。No. II 、No. IVは解析結果の方が全体的に変形量が大きく、No. IIIは垂壁部分の変形量が実験値より小さいが、ほとんど差はなく、 おおむね解析結果は実験值を捉えているといえる。

供試体No．I の柱脚変形量を図14に示す。土台と柱の空きを測定 したパイ型変位計が測定限界を超えてはずれ、測定が中途で終了し ているが、解析は実験値をほぼ追従している。

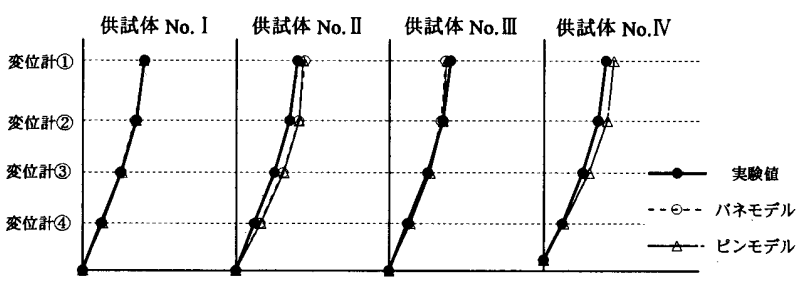

図13 C4の変形状態

注）実験值は層問変形角 $1 / 150 \mathrm{rad}$ 以内のデータの平均值
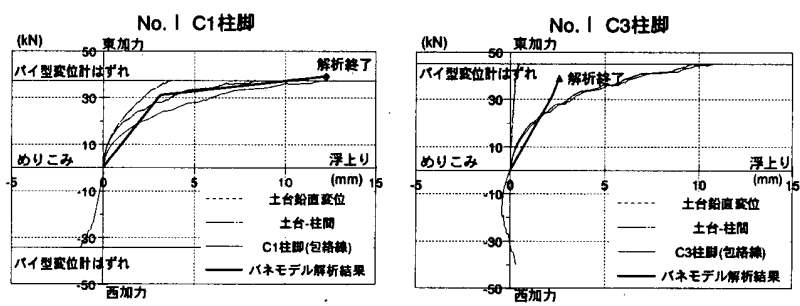

図14 柱脚の浮上りとめりこみ

各供試体について、図15に東側柱頭の荷重一変位関係、実験と解 析結果の破壦性状を示す。No. IVについては垂壁降伏後の解析值が 実験結果よりもやや低めの評価となっている。これは三角金物を使 用していない接合部を回転自由としていること、三角金物で接合し た梁 (G2) の剛性に合板の効果を全く考慮していないためと考えられ る。全体的にみて解析結果は実験とほほ一致しており、構造計算に 用いるための精度は確保できていると考えられる。 

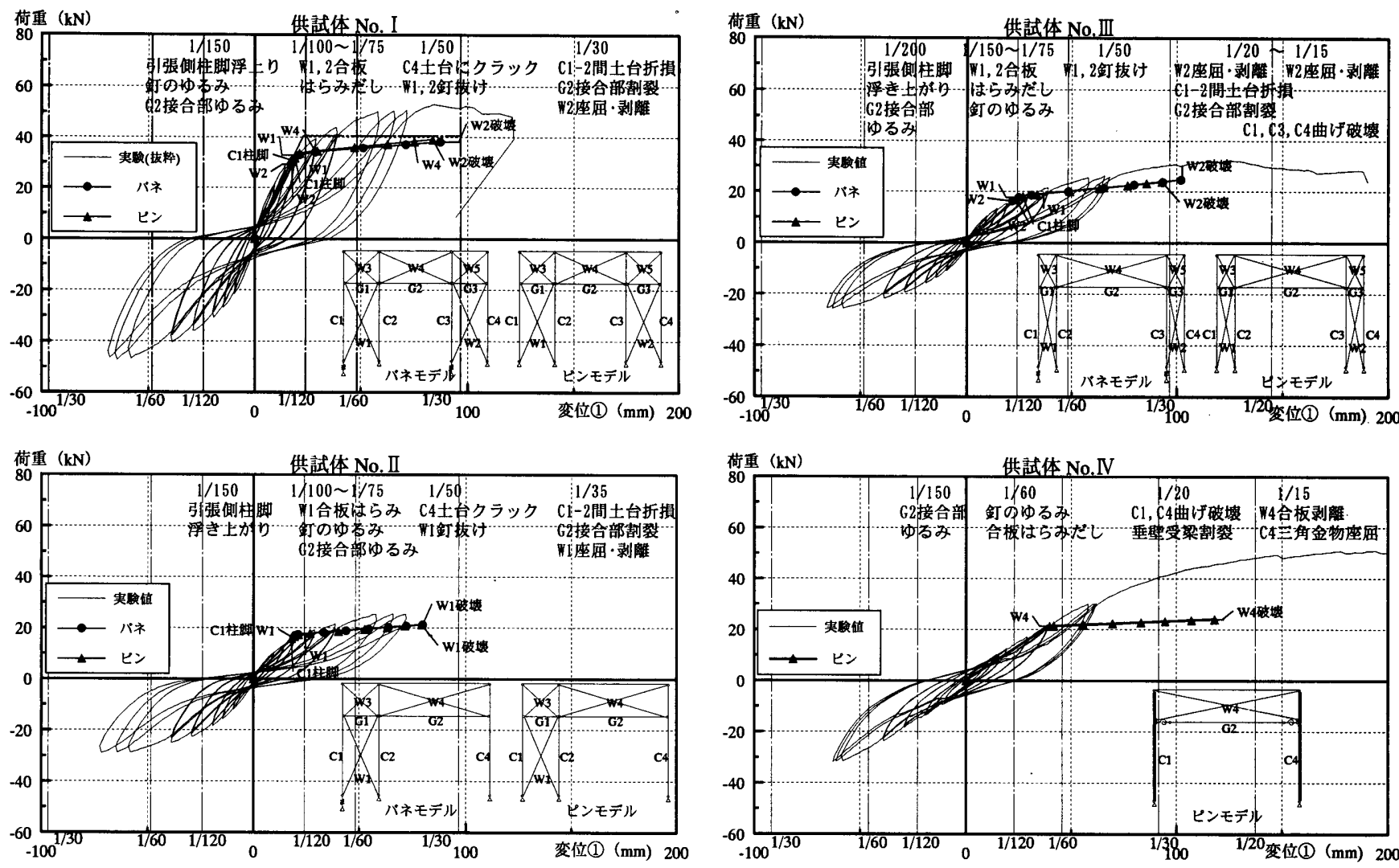

図15 荷重一変位曲線（実験値と解析值）

\section{3 階建て住宅の解析}

\section{1 建物概要}

実際に施工されている 3 階建て住宅の間口方向（X方向）につい て静的增分解析を行う。表4に構造部材の仕様とモデル化を示す。 図18に各階伏図と耐力壁の配置、図19に軸組形状としてY1通り軸 組図とモデル図を示す。1階には腰壁がないため 3 階建てを 8 層に モデル化しする。小屋組の架構は解析には含めず、軒高レベルで水 平な架構とする。

建物の特徵は、1 階Y 1 通りを柱 $(120 \times 270)+$ 垂壁の架構として いることと、まぐさ・窓台に柱と同サイズの部材を用い、クレテッ ク金物により接合していること、床版に板厚 $24 \mathrm{~mm}$ の合板を使用して いることである。 2 ・ 3 階においては、釘打ちした床合板の上から 壁合板受材をラグスクリューで梁に接合し、壁合板は受材に釘打ち している。受材と梁の接合部の剛性は考慮せず、一体とみなして解 析を行う。

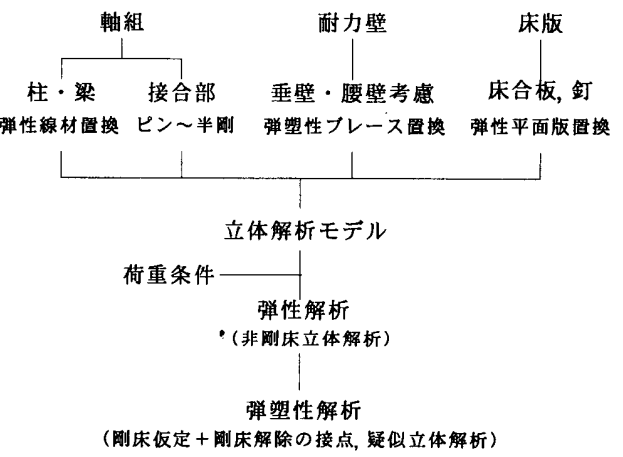

図16 解析手順

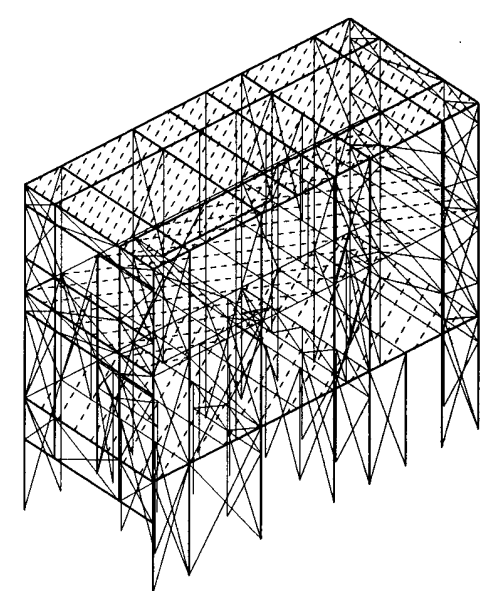

図17立体解析モデ

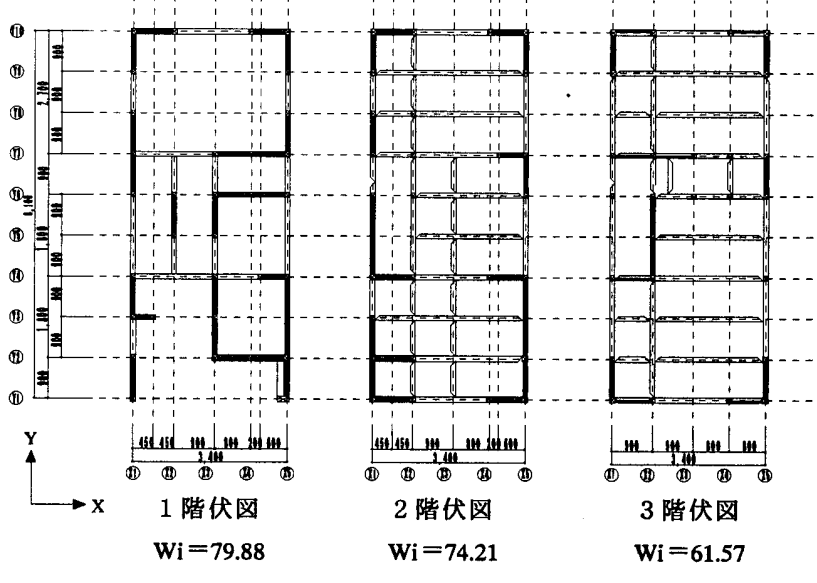

図18各階伏図 


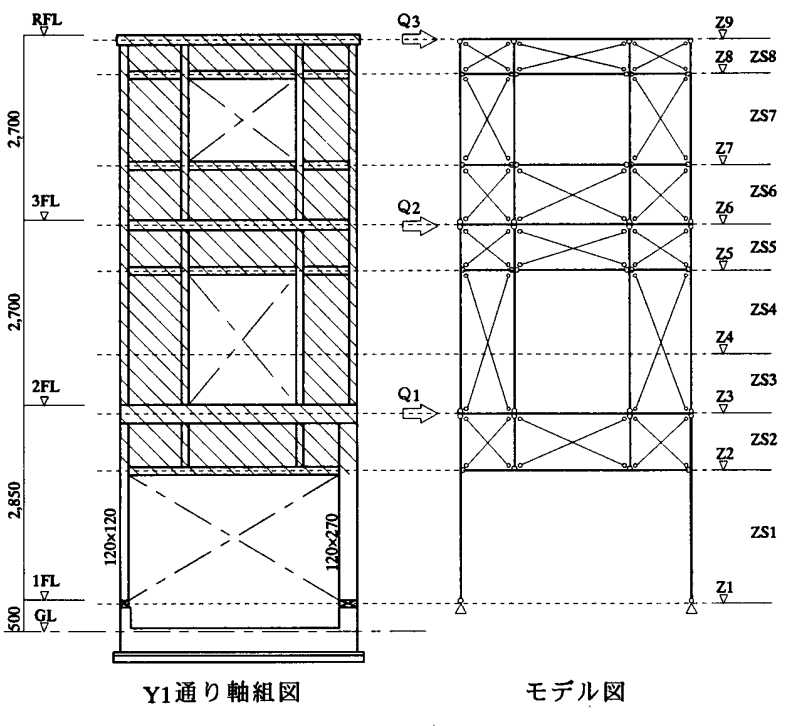

図19軸組形状

表4 構造部材の仕様とモテル化

\begin{tabular}{|c|c|c|c|}
\hline \multirow{2}{*}{ 軸組 } & 柱 & 構造用集成材 & \multirow{2}{*}{ 弾性線材置換 } \\
\hline & はり & 普通構造材 & \\
\hline \multirow{4}{*}{$\begin{array}{l}\text { 接 } \\
\text { 合 } \\
\text { 部 }\end{array}$} & 床梁 & 蟻＋羽子板金物 & ピン接合 \\
\hline & まぐさ·空台 & クレテック金物 & ピン接合 \\
\hline & 柱頭 & 短ほぞ+金物 & ピン接合 \\
\hline & 柱脚 & 短ほぞ+金物 & 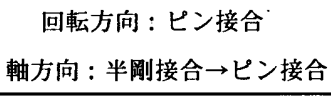 \\
\hline \multicolumn{2}{|r|}{ 耐力壁 } & 合板四周釘打ち & 弾塑性ブレース置換 \\
\hline \multicolumn{2}{|r|}{ 床版 } & 合板四周釷打ち & 平面版 $\rightarrow$ 甽床 \\
\hline
\end{tabular}

\section{2 部材特性}

4. 2.1 柱・梁部材

軸組材は弾性の線材に置換し、軸・曲げ・せん断剛性を考慮する (表5)。ブログラムの制約として、梁材に関しては水平方向の曲げ 及びせん断剛性は考慮されない。

表6に柱・梁部材の仕様を示す。柱・梁の耐力は、ほぞ穴の断面 欠損を考慮して断面定数を $80 \%$ として算定する。ほぞ穴は部分的な ものであるため、剛性には断面欠損を考慮しない。

表5 部材の剛性評価

\begin{tabular}{|c|c|c|c|c|}
\hline & 軸剛性 & 曲げ剛性 & せん断剛性 & ねじり剛性 \\
\hline 柱部材 & 0 & 0 & 0 & $\times$ \\
\hline 梁部材 & 0 & $\begin{array}{l}\text { 鉊直: } \bigcirc \\
\text { 水平 : } \times\end{array}$ & $\begin{array}{l}\text { 銛直: } \bigcirc \\
\text { 水平 : } \times\end{array}$ & $x$ \\
\hline
\end{tabular}

表 6 柱・梁部材

\begin{tabular}{|c|c|c|}
\hline 部位 & 断面 & 材質 \\
\hline \multirow[t]{2}{*}{ 柱 } & $120 \times 120, \quad 105 \times 105$ & E85-F300, 欧州アカマツ \\
\hline & $120 \times 270$ & E120-F330, 欧州アカマツ \\
\hline 床梁 & $105 \times 120 \sim 120 \times 270$ & 普通構造材, ベイマッ \\
\hline まぐさ, 空台 & $120 \times 120, \quad 105 \times 105$ & 普通構造材, ベイッカ \\
\hline
\end{tabular}

\section{2.2 合板钉打ち耐力壁}

合板釷打ち耐力壁の仕様は表7の通りとする。耐力壁の特性は、 3.3 .3 合板釘打ち耐力壁 と同様で、式(5)，(6)により剛性之耐 力を計算する。塑性剛性はブログラム内部の值とし、弾性剛性の $10^{-6}$ 倍として解析を行う。

表7 合板釘打ち耐力壁の仕様

\begin{tabular}{|c|c|c|c|c|}
\hline & \multirow{2}{*}{ 構造用合板 2 級 } & \multicolumn{3}{|c|}{ 釘 CN50 } \\
\cline { 5 - 5 } & & ピッチ & すべり剛性 & 降伏耐力 \\
\hline 1,2 階 & $9 \mathrm{~mm}$, 両面張り & \multirow{2}{*}{100} & $1250 \mathrm{~N} / \mathrm{mm}$ & $590 \mathrm{~N}$ \\
\hline 3 階 & $9 \mathrm{~mm}$, 片面張り & & & \\
\hline
\end{tabular}

\section{2.3 床合板}

床版は、面内において岡性を考虑する。水平剛性は、合板釘打ち 耐力壁の剛性と同様に、釘のすべりと合板のせん断弾性係数から式 (5)により求める。式 (7)により、合板のせん断弾性係数を用いて等 価なせん断剛性を持つ板厚 $t^{\prime}$ の弾性平面版要素に置換する。面外に 関しては剛体として扱う。また、床版により梁の曲け剛性が増大す ることはないとする。床版の仕様を表8に示す。 2,3 階の床版は、 合板厚 $24 \mathrm{~mm}, \mathrm{CN} 75$ を使用するが、釘のすべり剛性は合板釘打ち耐力 壁と同じ値とする。

$$
t^{\prime}=\kappa \cdot k_{s} \frac{h}{G \cdot l}
$$

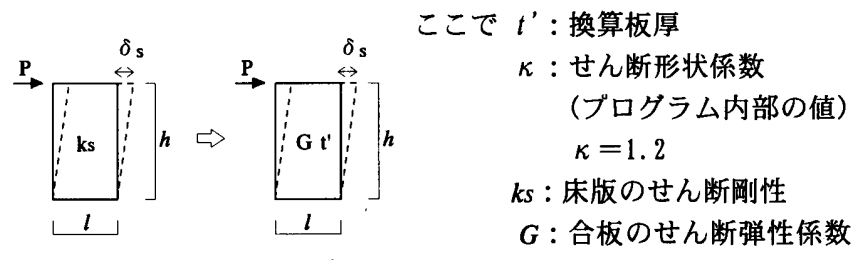

表8，床版の仕様

\begin{tabular}{|c|c|c|c|c|c|}
\hline & \multirow{2}{*}{$\begin{array}{c}\text { 構造用合板 } \\
G=400.0 \mathrm{~N} / \mathrm{mm}^{2}\end{array}$} & \multicolumn{3}{|c|}{ 釘 } & \multirow{2}{*}{$\begin{array}{r}\text { 換算板厚 } \\
t^{\prime} \quad(\mathrm{cm})\end{array}$} \\
\hline & & 種別 & ピッチ & すべり剛性 & \\
\hline 2,3階 & $24 \mathrm{~mm}$, 根太なし，4周釘打 & CN75 & 150 & $1250 \mathrm{~N} / \mathrm{mm}$ & 0.60 \\
\hline 屋根 & $12 \mathrm{~mm}$, 垂木45×45@364 & $\mathrm{N} 50$ & 150 & --- & 0.10 \\
\hline
\end{tabular}

\subsection{4 壁剛性低減率}

壁剛性低減率は表9の值とする。垂壁・腰壁のない耐力壁は式(1)、 垂壁の付いた耐力壁は実大実験の解析結果から值を決定した。垂壁 と腰壁の付いた耐力壁は、実験の解析と同様の解析を行って值を決 定した (図20)。柱脚金物の剛性はすべて実験供試体と同じと仮定し、 金物の終局耐力は短期許容耐力の $3 / 2$ 倍とする。
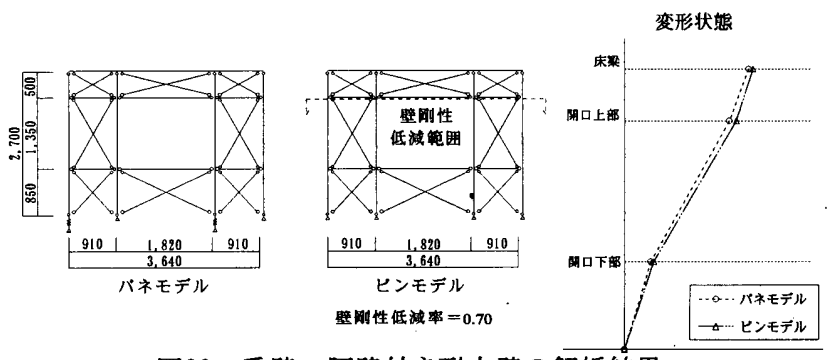

図20垂壁・腰壁付き耐力壁の解析結果 
表9 壁剛性低減率

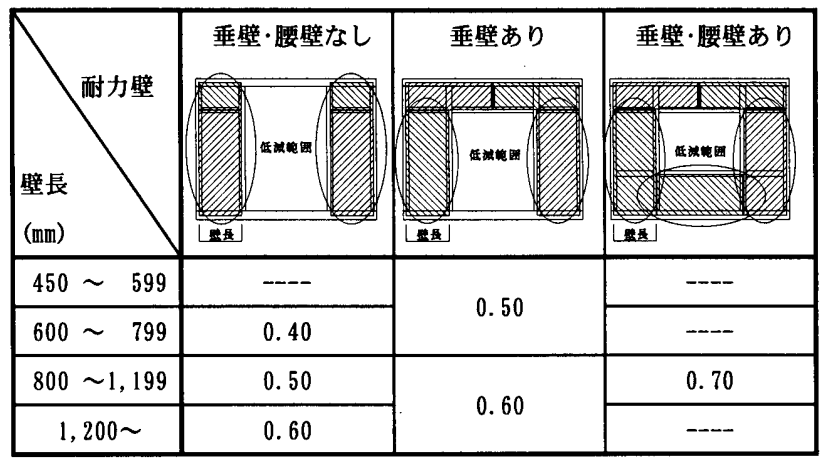

\section{3 荷重}

林の固定荷重と積載荷重 (表10) は、床面 $(23, Z 6, Z 9)$ に等分布荷重 として入力する。壁の固定荷重は、壁上下の床梁がそれぞれ $1 / 2$ 負 担するものとし、床梁の等分布荷重として入力する。

水平荷重は、層せん断力係数 $\mathrm{C}_{0}=1.0$ の $\mathrm{A}_{\mathrm{i}}$ 分布荷重とする （表11）。プログラム上では、各節点における鈶直荷重に比例した水 平力が各節点に入力される。

表10 積載荷重と固定荷重

$\left(\mathrm{N} / \mathrm{m}^{2}\right)$

\begin{tabular}{|c|c|c|c|c|}
\hline \multirow{2}{*}{ 部位 } & \multirow{2}{*}{ 仕上け等 } & \multirow{2}{*}{ 固定荷重 } & \multicolumn{2}{|c|}{ 積載荷重 } \\
\cline { 4 - 5 } & & & 架構用 & 地震力用 \\
\hline 屋根 & 彩色スレート & 700 & 300 & 300 \\
\hline 2,3 階床 & フローリング, 畳 & 600 & 1300 & 600 \\
\hline バルコニー & 既製品 & 350 & 1300 & 600 \\
\hline 外壁 & サイディング & 600 & & \\
\hline 内壁 & ボード貼り & 400 & & \\
\hline
\end{tabular}

表11 水平荷重

$(\mathrm{kN})$

\begin{tabular}{|c|c|c|c|c|c|c|c|}
\hline & $M \mathrm{i}$ & $\Sigma W_{i}$ & $\alpha$ & $\mathrm{C}_{0}$ & $\mathrm{Ai}$ & $\mathrm{Ci}$ & $Q$ \\
\hline 3階 & 61.57 & 61.57 & 0.285 & 1.000 & 1.483 & 1.483 & 91.28 \\
\hline 2 階 & 74.21 & 135.78 & 0.630 & 1.000 & 1.192 & 1.192 & 161.83 \\
\hline 1 階 & 79.88 & 215.66 & 1.000 & 1.000 & 1.000 & 1.000 & 215.65 \\
\hline
\end{tabular}

\section{4 解析結果}

図21に各階の荷重一変位曲線を、図23に破壊形式を示す。荷重 係数は $\mathrm{C}_{0}=1.0$ に対する值であり、ステップ 1 は $\mathrm{C}_{0}=0.0$ の時であ る。 $\mathrm{C}_{0}=0.7447$ （ステップ15）時に 3 階の耐力壁が全て降伏して 終局に達した。終局時の最大層間変形角は 1 階が $1 / 37 、 2$ 階が $1 / 67$ 、 3 階が1/33（全てY1通り）となった。

図23 を見ると、実大実験の解析結果と異なり、開口横の壁の降 伏より 2 -3階の垂壁の降伏が早くなっている。これは $2 \cdot 3$ 階に おける階高と垂壁の高さの比 (500/2700)が実験供試体 (830/2900)よ りも小さいためと思われる。1 階は垂壁の降伏の方が遅く、終局時 には全ての耐力壁で垂壁+柱の架構となっている。

図22にY1，Y10通りの終局時モーメント図を、図24に終局時に おける耐力壁と柱のせん断力分布図を示す。1 階 Y1通りには耐力 壁がないが、終局時にはX5通りの柱 $(120 \times 270) 1$ 本で壁長900の耐 力壁と同等のせん断力を負担しており、柱が有效に働いていること がわかる。
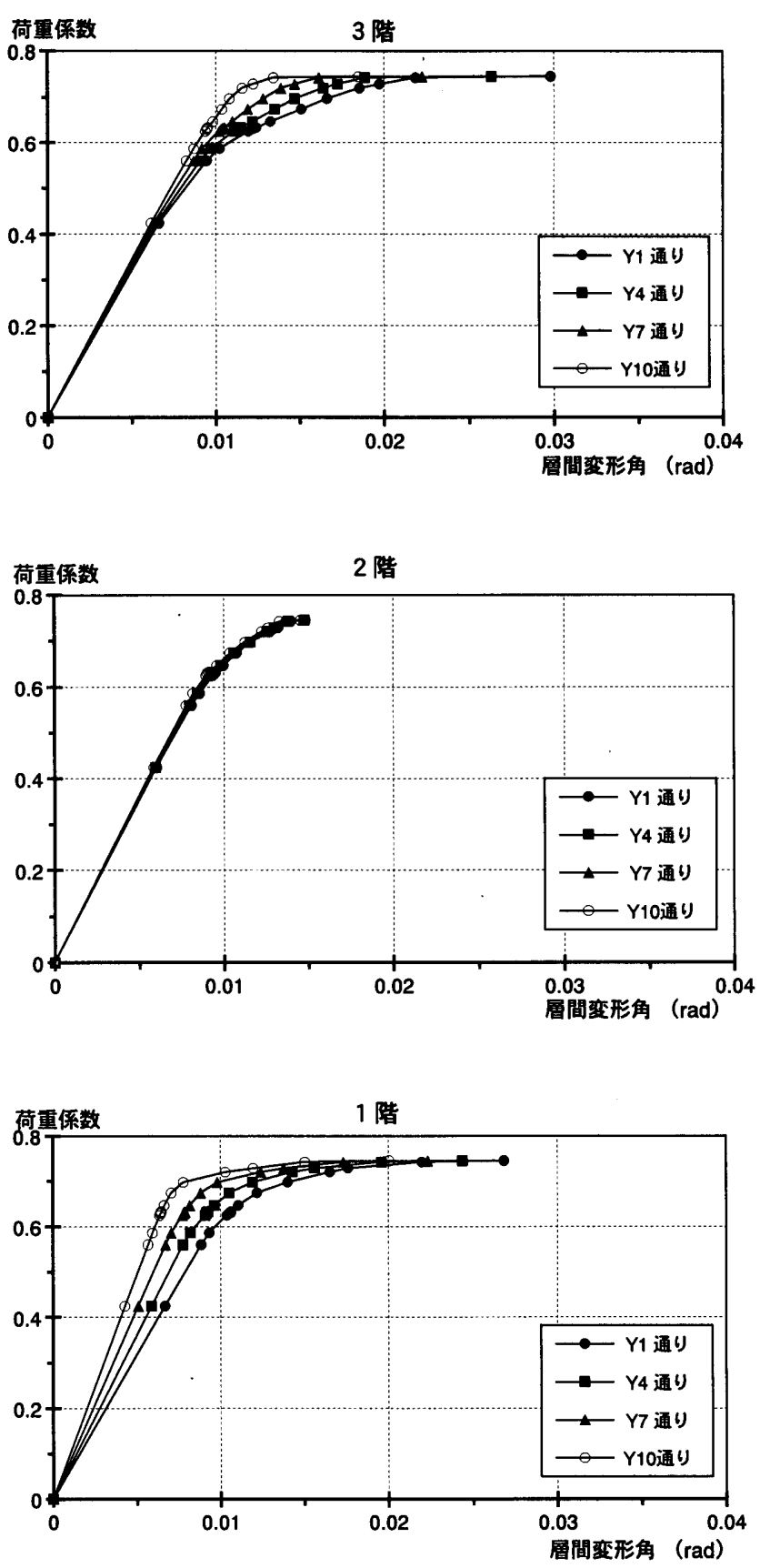

図21各階の荷重一変位曲線
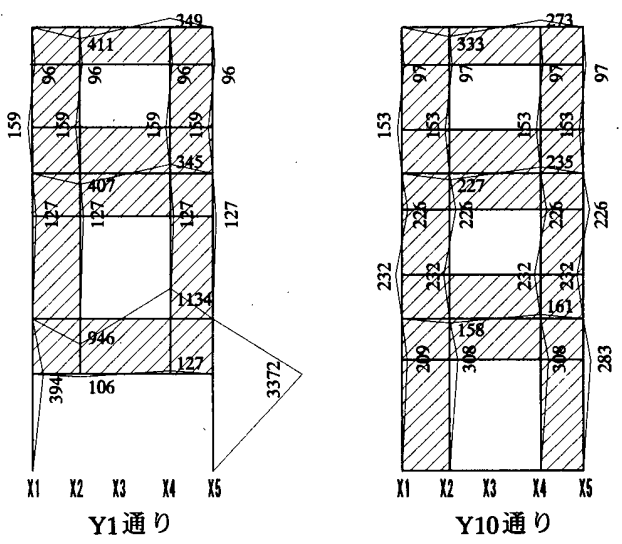

図22＼cjkstart終局時モーメント図 $(\mathrm{kNcm})$ 


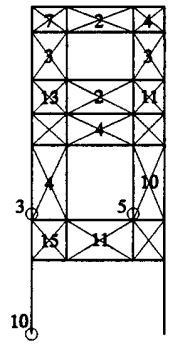

Y1通り

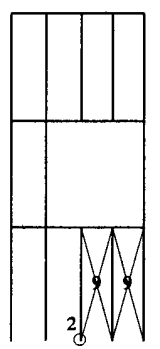

Y6通り

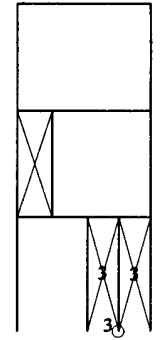

Y2通り

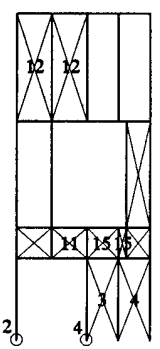

Y7通り

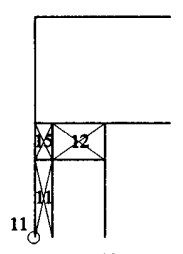

Y3通り

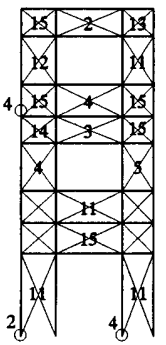

Y10通り

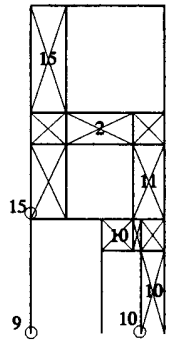

Y4通り
図23破壊形式

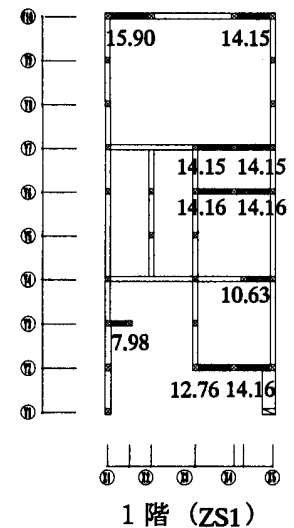

1 階（ZS1）

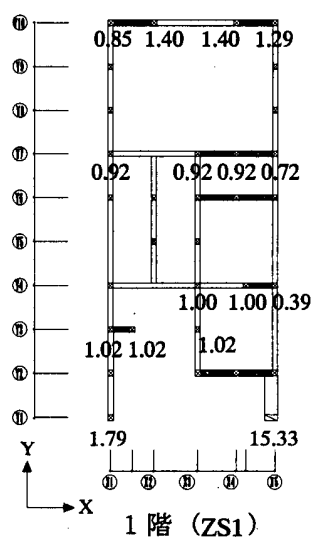

壁せん断力

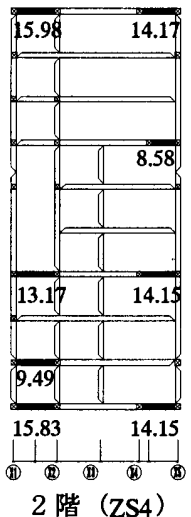

柱せん断力

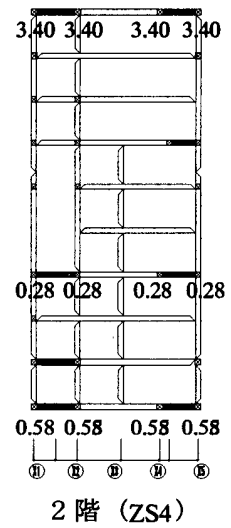

2 階（ZS4）

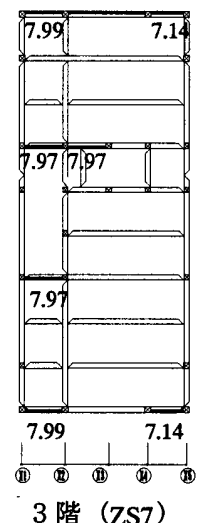

3 階（ZS7）

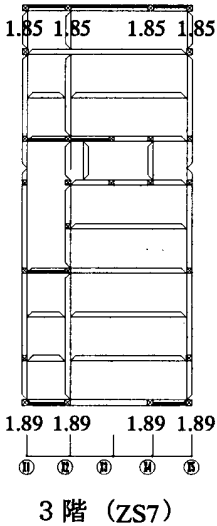

図24 終局時水平力分布図 $(\mathrm{kN})$

注）数値のない柱のせん断力は 0.0

\section{5. まとめ}

木構造の各構造要素および木構造特有の接合部の固定条件等の力 学的特性に関して、デタが完備した状態とは言い難く、現時点で すべてを正当に評価した上で解析を行うことは困難である。そのた め、解析精度は接合部や各構造要素の力学的特性に左右されるが、 データが揃えば、「壁量」の計算法よりは精度の高い解析が可能で ある。実験と解析により得られた成果を以下に示す。

(1) 簡便な手法により、実用としては十分な精度の弾塑性解析を行 うことができる。

(2) 垂壁・䁏壁と柱の特性を解析に取り入れることができる。

今後はより精度の高い解析とするために、以下の項目について検 討を行う必要があると考えられる。

(1) 接合部の特性を正確に把握する。

(2) 柱・梁部材の応力について、実験結果との比較検討を行う。

(3) 柱脚の浮上りに関して、長期鈶直荷重の押さえ効果を評価する。

(4) 連層の架構とした場合について検証を行う。

(5) 直交方向の構造要素の効果や、捻れについての検証といった立 体架構についての検証を行う。

(6) 合板釘打ち耐力壁以外の木造建築に適用するための検討を行う。

\section{謝辞}

本論を構想し、まとめるにあたり貴重なご指導を頂いた甲津功夫 先生, 小松幸平先生, 大橋好光先生, 宮沢健二先生に厚く御礼申し 上げます。また、本論の提案や実験に多大のご支援を頂いた金城一 守氏に深い感謝の念を捧げます。

\section{参考文献}

1）宮澤健二、：せん断パネル理論による木質面材釷打ち有開口耐力壁の略 応力解析法、日本建築学会構造系論文報告集、No. 487、pp. 113-120、 1996. 9

2）伊藤聡、宮澤健二、重藤功光、戸田淳二 : 枠組壁構法住宅の立体弹望性 有限要素法解析に関する研究（その 1,2$)$ ，日本建築学会大会学術 講演梗概集、No. 22045 22046、pp. 89-92、2000.9

3）佐野裕、湯田哲也、伊藤洋路、片岡良二、宮澤健二：軸組構法立体弹望 性解析に関する研究（その $1 ， 2$ ）、日本建築学会大会学術講演梗概 集、No. 22049 22050、pp. 97-100、2000.9

4）宮澤健二、：合板耐力壁を含む集成材剛接架構の応力性状と変形性能に 関する研究、日本建築学会構造系論文報告集、No. 527、pp. 125-132、 2000.1

5）中山佳織、稲山正弘、村上雅英、後藤正美 : 在来軸組工法木造住宅の構 造設計手法の開発（その 7)、日本建築学会大会学術講演梗概集、 No. 22097、pp. 191-192、1998.9

6) 稲山正弘、村上雅英、後藤正美 : 在来軸組工法木造住宅の構造設計手法 の開発（その17）、日本建築学会大会学術講演梗概集、NNo.22124、 pp. 247-248、1998. 9

7）今泉勝吉ほか 19 名：1998年 枠組壁工法建筮物構造計算指針、(社) 日本 ツーバイフォー建築協会、pp. 64, 79-80

8）下徳辺一、村上雅英、三澤文子、田原賢 : 各種引き笴せ金物の耐力と剛 性の評価、日本建築学会大会学術講演梗概集、No. 22035、pp. 69-70、 1996.9

9）大野吉昭、岡部実、河合直人、高田清二 : 枠組壁工法耐力壁のせん断耐 力及び剛性（その 2 ）釷接合部の一面せん断試験と降伏理論の適用、 日本建策学会大会学術講演梗概集、No. 22049、pp. 97-98、1999.9

10）木構造設計資料 FA-7 合板を側材とする釬接合、(財) 日本住宅・木材 技術センター、pp.4、1991.3 